\title{
Environmental Law and Private Law
}

\section{David Howarth}

\section{Introduction}

The relationship between environmental law and private law has long been controversial and unhappy. Environmental lawyers have often been suspicious of private law, seeing it as steeped in individualism and as not committed to basic collective principles such as the polluter-pays and precautionary principles. In return, private lawyers have tended to see environmental law as a disturbing mélange of different types of law, devoted not to upholding rights and providing justice between the parties but to politically determined policy goals. The two sides seem to agree on only one thing: that environmental law and private law do not mix and should as far as possible be isolated from each other. ${ }^{1}$ The image presented by both sides is of a fixed and antagonistic relationship, an image further dogged by stereotypes and overgeneralizations, for example about differences between the common law and civil law.

The purpose of this chapter is not to contribute directly to the controversy, or indeed to the unhappiness, surrounding the relationship between environmental law and private law-although it is worth noting that the balance of the debate has shifted again towards recognizing the importance of private law in the development of environmental controls, at least as long as private law claimants are themselves driven by concern for the environment. ${ }^{2}$ Its purpose instead is to describe the variety that exists across different legal systems in how the two relate to each other. In doing so, it hopes to widen the range of solutions and techniques available to lawyers in different jurisdictions. It is an exercise not in developing a definitive answer to the question of how environmental law and private law should interact but in preparing a catalogue of the ways in which they might interact. Before doing that, however, we need to clear the ground by setting out what we mean by private law.

\footnotetext{
${ }^{1}$ S. Bell, D. McGillivray, and O. Pedersen, Environmental Law (Oxford: Oxford University Press, 2013), 280-3; P. Cane, 'Using Tort Law to Enforce Environmental Regulations?' (2002) 41(3) Washburn Law Journal 427-68.

${ }^{2}$ B. Pontin, Nuisance Law and Environmental Protection: A Study of Nuisance Injunctions in Practice (Witney: Lawtext, 2013).
} 


\section{What Is Private Law?}

One of the most important lessons of comparative law is that unless handled with care legal transplants can cause trouble. ${ }^{3}$ The very concept of 'private law' is such a transplant. Its origin is in Roman law. As the Institutes say: ${ }^{4}$

Huius studii duae sunt positiones, publicum et privatum. publicum ius est quod ad statum rei Romanae spectat, privatum quod ad singulorum utilitatem pertinet. dicendum est igitur de iure privato, quod tripertitum est; collectum est enim ex naturalibus praeceptis aut gentium aut civilibus.

The concept of private law, for the most part stripped of any reference to ius gentium and ius naturale, passed into those modern legal systems heavily influenced by Roman law, particularly the French and the German systems, in which the jurisdictional structure of the courts reinforces the distinction between private and public law. Lawyers and philosophers from other systems, particularly systems derived from English law, have long found the distinction difficult. Lacking separate courts for public and private law litigation and, more importantly, lacking a clear theory of the state and so a distinct idea of public law, ${ }^{5}$ many of them struggle to make sense of private law as a category. ${ }^{6}$ They confuse it with common law as opposed to statutory law, worry that use of the word 'private' implies a claim that the state is somehow not involved in private law, and resort to arguments aimed at establishing not that private law is a distinct category but rather that it ought to be. ${ }^{7}$

This not to say that all the definitions of private law used in Roman law-derived systems are themselves satisfactory. The idea, for example, that private law comprises all the legal rules that derive from recognising the principle of individual autonomy or freedom of the will, an idea prominent in German legal thought, at least in twentieth-century interpretations of nineteenth-century debates, ${ }^{8}$ if taken literally would artificially restrict the range of what can count as private law. For example, strict liability torts might not obviously derive from the concept of individual autonomy.

Another approach might be to say that individual autonomy is important to private law, marking it out from other forms of law, in a different way: not so much in the properties of the rules themselves, which may or may not have a basis in the concept of freedom of the will, as in what individuals can do with them. In private law, on this point of view, individuals can choose to press their claims or to drop them or to settle them as they wish. But this approach has its own flaws. The ability to press or drop claims is not excluded from other fields of law. Historically, many legal systems treated crimes as capable of being settled by

\footnotetext{
${ }^{3}$ For a summary of the long-running debate on legal transplants see A. Bakardjieva Engelbrekt, 'Legal and Economic Discourses on Legal Transplants: Lost in Translation?' in P. Wahlgren (ed.), Scandinavian Studies in Law vol 60: Law and Development (Stockholm: Stockholm Institute for Scandinavian Law, Law Faculty, Stockholm University, 2015), 111-40.

${ }^{4}$ Tribonian, Institutiones (Constantinople: Justinian, 533), Lib I, Tit I.

${ }^{5}$ See generally M. Loughlin, Public Law and Political Theory (Oxford: Clarendon, 1992); J. Allison, A Continental Distinction in the Common Law (Oxford: Oxford University Press, 1996).

${ }^{6}$ W. Lucy, The Philosophy of Private Law (Oxford: Oxford University Press, 2006), 436.

${ }^{7}$ Ibid., at 12-21.

${ }^{8}$ See generally S. Hofer, Freiheit ohne Grenzen? privatrechtstheoretische Diskussionen im 19. Jahrhundert (Tübingen: Mohr Siebeck, 2001).
} 
victims, and exceptionally some still do, even for murder. ${ }^{9}$ Moreover, public law litigants can choose to press or drop their claims, even though limitations might exist on their ability to settle (e.g. accepting money in settlement of claim that a public authority lacked the power to make a decision suffers from the inherent defect that a claimant's agreement cannot create a power that does not exist).

Furthermore, any attempt to derive the content of private law from the value of freedom or autonomy can be criticized as an unnecessarily ideological exercise. As those who worked on the European Private Law Draft Common Frame of Reference recognized, private law is capable of responding to a wide range of principles and values, which they grouped under the headings freedom, security, justice, and efficiency. ${ }^{10}$ Despite the hopes and fears of some writers, ${ }^{11}$ no necessary connection exists between the mere existence of private law and any specific political programme. On the contrary, private law rules can be designed that further or complement a wide variety of political or policy goals.

The conclusion that private law can be used for a variety of purposes, however, is not without its own critics. Some writers object to the very idea of designing private law rules to achieve public policy goals, ${ }^{12}$ and many of these writers also object to public policy-making by judges. ${ }^{13}$ These authors, however, either openly acknowledge that they are engaged in a normative rather than an analytical exercise, with its own essentially ideological purpose of isolating private law from politics, or else claim to be setting out an 'interpretation' of the existing law in a very limited range of jurisdictions, usually England or the United States. ${ }^{14}$ The point about the capability of courts is separate, but seems to confuse private law with common law. The limitations of judges as makers of public policy do not apply to legislators, and so cannot be used to criticize the provisions of statutes or codes.

For comparative purposes we should aim as far as possible to avoid the twin traps of parochialism and ideology. Since the concept of private law itself derives from actual legal systems, and not from a more abstract theory, it is arguably impossible fully to achieve universality and neutrality. Any conception of private law we adopt will inevitably be open to criticism. But on the basis that we need a rough tool for immediate use and not a

${ }^{9} \mathrm{M}$. Dyson (ed.), Comparing Tort and Crime: Learning from across and within Legal Systems (Cambridge: Cambridge University Press, 2015); R. Peters, Crime and Punishment in Islamic Law: Theory and Practice from the Sixteenth to the Twenty-First Century (Cambridge: Cambridge University Press, 2006), 146.

${ }^{10} \mathrm{C}$. von Bar, E. Clive, and H. Schulte-Nölke, Principles, Definitions and Model Rules of European Private Law: Draft Common Frame of Reference (DCFR) (Munich: Sellier, 2009).

${ }^{11}$ e.g. M. Streit, 'Economic Order, Private Law and Public Policy, The Freiburg School of Law and Economics' (1992) 48(4) Journal of Institutional and Theoretical Economics 675-704; D. Singh Grewal and J. Purdy, 'Introduction: Law and Neoliberalism' (2014) 77(4) Law \& Contemporary Problems 1-23.

${ }^{12}$ e.g. Ernest Weinrib, The Idea of Private Law (Oxford: Oxford University Press, 2012).

${ }^{13}$ P. Cane, 'Rights in Private Law' in D. Nolan and A. Robertson (eds.), Rights and Private Law (Oxford: Hart Publishing, 2012), 35-64, 41.

${ }^{14}$ D. Nolan and A. Robertson, 'Rights and Private Law' in Nolan and Robertson (eds.), Rights and Private Law, at 1-34, 5. See generally J. Goudkamp and J. Murphy, 'The Failure of Universal Theories of Tort Law' (2015) 21(2) Legal Theory 47-85. 
perfectly honed scientific instrument, I propose to count as private law any rule or body of legal rules that purports to govern legal relationships or disputes between parties who are not acting as state officials or bodies.

We make three observations about this conception of private law. First, the reference to 'legal relationships or disputes' is designed to cover both contracts, which are first and foremost relationships and only exceptionally give rise to disputes, and torts/delicts, which are the opposite. Second, we refer to what the rules themselves purport to do and not directly to the nature of parties, so that the possibility that a rule might be used additionally to govern a relationship between a citizen and the state, for example when the state acts as a fisc and not as a sovereign, does not disqualify the rule as a rule of private law. Third, the intention of the rider 'not acting as state officials or bodies' is to exclude both criminal law and public law. This is perhaps the main weak point of the definition, since it presupposes a clear legal theory of the state and so we must tolerate some loss of analytical power when dealing with systems that lack such a theory.

The third observation has an important consequence. A literature exists in English about what is called 'civil liability' for environmental damage. ${ }^{15}$ The term is, however, confusing, since in this context the word 'civil' merely means 'not criminal'. It does not rule out regulatory liability, in the sense of duties to pay sums of money to state bodies but not to individual victims. Indeed the possibility of regulatory liability has led to the possibly strange concept of a 'civil penalty', where the sum due exceeds the value of the damage caused but the process of imposing it is not 'criminal'. ${ }^{16}$ That means that, according to this usage, as odd as it might seem to the intellectual descendants of Trebonian, 'civil' liability is not necessarily liability in private law. For example, the system of regulatory liability envisaged by the EU's Environmental Liability Directive ${ }^{17}$ is often classified in Englishspeaking jurisdictions as 'civil' liability, even though, admittedly after much hesitation, that Directive deliberately chose not to create private law rights and duties. ${ }^{18}$ The confusion is reinforced by including within the category of 'civil liability' cases of true private law liability, for example liability for damage caused by nuclear accidents as required by the Paris Convention of 1960 (as implemented by, for instance, the UK's Nuclear Installations Act 1965) and cases of combinations of private law and regulatory liability, for example the regime required by the treaties on marine oil pollution. ${ }^{19}$

${ }^{15}$ e.g. Mark Wilde, Civil Liability for Environmental Damage: A Comparative Analysis of Law and Policy in Europe and the US (The Hague: Kluwer, 2013).

${ }^{16}$ R. White, "It's not a criminal offence" - Or Is It? Thornton's Analysis of "Penal Provisions" and the Drafting of "Civil Penalties"' (2011) 22(1) Statute Law Review 17-37; M. Jefferson, 'Regulation, Businesses, and Criminal Liability' (2011) 75(1) Journal of Criminal Law 37-44.

${ }^{17}$ Directive 2004/35/CE of the European Parliament and of the Council of 21 April 2004 on environmental liability with regard to the prevention and remedying of environmental damage

${ }^{18} \mathrm{M}$. Hinteregger, Environmental Liability and Ecological Damage in European Law (Cambridge: Cambridge University Press, 2008), 5-25; Bell, McGillivray, and Pedersen, Environmental Law, at 391.

${ }^{19}$ Hinteregger, Environmental Liability and Ecological Damage in European Law, at 26-8. 


\section{Two Aspects of the Relationship Between Environmental Law and Private Law}

Another important distinction is between two different kinds of interaction between environmental law and private law. The first kind of interaction starts with private law and asks how it might be relevant to the subject matter of environmental law, for example how private law might serve to deter or repair environmental damage. The second kind of interaction starts with environmental law and asks how it affects private law, for example whether environmental regulation is recognized and given effect in private law. The first might be called private law as environmental law, the second environmental law in private law. The two types of interaction themselves interact. The extent to which a legal system allows environmental law to affect private law will help to define the role of private law as environmental law in that system. But the two issues are distinct.

\subsection{Private Law as Environmental Law}

Private law can act as environmental law in three distinct ways. First, it can facilitate agreements that protect the environment. Second, it can grant rights to sue in respect of acts or activities that harm the environment. Third, it can refuse to facilitate agreements that harm the environment. In most legal systems the first is a matter of contract and property law, the second of tort/delict or property law, and the third mainly of contract law. ${ }^{20}$ Jurisdictions vary in the extent to which their systems of private law function in these ways.

\subsubsection{Agreements Protective of the Environment}

Sceptics about the utility of private law as environmental law point out that many environmental problems arise precisely because of the limitations of the concept of property. ${ }^{21}$ Shared environmental interests, such as biodiversity and the climate, belong to no one and are thus unprotected by property law. But no reason exists in principle (as opposed to political reasons or reasons of practicality) why such interests should not come within the scope of property rights. ${ }^{22}$ Moreover, even if property regimes do not extend to such interests, private law in the form of contract law can create obligations to act in particular ways about them regardless of whether those acts themselves relate to property

\footnotetext{
${ }^{20}$ Note, however, that classification within private law is a notorious source of confusion in comparative law. For example, what English lawyers think of as the tort of nuisance is classified in some jurisdictions as a matter of property law and German lawyers think of all legal issues arising out of the negotiation of a contract as part of contract law whereas in most other jurisdictions they can also be matters of tortious or delictual liability. The best approach is probably not to give too much weight to issues of classification.

${ }^{21} \mathrm{~J}$. Holder and M. Lee, Environmental Protection, Law and Policy (Cambridge: Cambridge University Press, 2007), 330; N. Stern, The Economics of Climate Change: The Stern Review (Cambridge: Cambridge University Press, 2007), 1, 25, and 36.

${ }^{22}$ See generally D. Cole, Pollution and Property: Comparing Ownership Institutions for Environmental Protection (Cambridge: Cambridge University Press, 2002) for a discussion of the practical and political problems.
} 
rights. In addition, to the extent that such contracts can themselves be securitized, the market can treat them as if they were property rights. These possibilities have prompted some commentators to claim that we are witnessing a 'contractualisation' of environmental law. ${ }^{23}$ Two types of contractualization can be identified: methods that channel selfinterested behaviour in pro-environmental directions; and methods that help altruistically motivated people to fulfil their own pro-environmental goals.

As an example of the former, we might consider cap-and-trade systems such as the European Union's Emission Trading System (EU ETS). Cap-and-trade systems work through the creation of new property rights, for example rights to emit greenhouse gases, which are capable of being the subject matter of contracts. The underlying concept is that if one engineers a private value for socially beneficial conduct, people will be more likely to act in that socially beneficial way. Admittedly, the property rights themselves rest on a base of criminal law and regulation. Permits to do something previously allowed can only exist if the activity is first made unlawful, and that unlawfulness is usually created by making the activity itself a criminal offence unless covered by a permit. But that process is not different in kind from the creation of other kinds of property. Property rights in objects, for example, are protected not just by private law remedies but also by criminal offences such as theft and criminal damage. Indeed, in the modern world criminal law is the primary method for making sure that property rights are enforceable not just against counter-parties in contracts but against everyone in the world ('erga omnes'). Even intellectual property regimes contain criminal offences. ${ }^{24}$ One might object that a system of tradable permits is different because the relevant offences can be committed by the owners themselves, and not exclusively by those who interfere in the owners' property, but that would be to miss the point that those who emit greenhouse gases without sufficient permits are interfering in the rights of others who hold permits. It is as if they are using other permit holders' rights without their permission.

Different legal systems, however, approach the creation of trading schemes in subtly different ways. Indeed the differences between legal systems in the EU was acknowledged in the Directive setting up the EU ETS. ${ }^{25}$ The detailed implementation of the system was left to the Member States' own legal systems, subject to the requirement that each Member State must provide for equal treatment of permits created in other Member States.

Differences include how particular systems create property rights that exist only for a certain length of time and which in some circumstances are defeasible by administrative action. The latter is particularly challenging because it produces the possibility of public law

${ }^{23}$ Y. Jégouzo, 'L'évolution des instruments du droit de l'environnement' (2008) 4(127) Pouvoirs 2333 , at 19.

${ }^{24}$ See e.g. L. Bently and B. Sherman, Intellectual Property Law (Oxford: Oxford University Press, 4th edn. 2014), 1263-9; C. Geiger (ed.), Criminal Enforcement of Intellectual Property (Cheltenham: Edward Elgar, 2012).

${ }^{25} \mathrm{M}$. Wemaere, C. Streck, and T. Chagas, 'Legal Ownership and Nature of Kyoto Units and EU Allowances in Freestone' in D. Freestone and C. Streck, Legal Aspects of Carbon Trading: Kyoto, Copenhagen, and Beyond (Oxford: Oxford University Press, 2009), 35-58, 49-51. 
litigation alongside and possibly in conflict with basic provisions of private law. ${ }^{26}$ In France, for example, the Conseil d'Etat has decided that the public authority has extensive powers to revoke ETS permits issued as a result of a mistake by an operator, ${ }^{27}$ but that raises the issue of what happens in private law if the operator had sold some of its permits to a third party and of the public law consequences if the third party suffers a loss. More generally, in systems such as the French, which draw strong distinctions between public and private property, the former being to some extent inalienable, explicit provision is required to ensure tradability. ${ }^{28}$

Another challenge for the EU ETS has been divergences between Member States about whether allowances are to be treated as 'goods' or not. ${ }^{29}$ The French Code de l'environnement declares that ETS permits are 'biens meubles' but that is not the case in other jurisdictions. The UK legislation, the Greenhouse Gas Emissions Trading Scheme Regulations 2012, is characteristically silent, since British legislation usually strives as far as possible to avoid matters of legal classification, but the courts have slipped easily into treating allowances as legitimate objects of ordinary contract law. ${ }^{30}$ The Markets in Financial Instruments Directive 2014 (MiFID II) treats all contracts in EU ETS allowances, including spot contracts, as financial instruments and thus subject to the relevant regulatory regime, albeit with some relaxation of its requirements for operators of relevant installations as opposed to traders in permits.

In the United States, because of concerns about triggering constitutional doctrines about expropriation, legislation creating emissions trading systems has tended to say that permits are not to be treated as property but nevertheless that they can be possessed and transferred. ${ }^{31}$ The apparent contradictions in this position serve only to reinforce the point that legislatures are at liberty to abuse the basic concepts of private law if that is what they want to do in the pursuit of their policy goals.

Turning to the latter type of 'contractualization', giving greater effect to altruistic action, we might point to the example of 'conservation covenants'. ${ }^{32}$ The idea is that covenants or easements on land can be used to promote conservation, for example to preserve biodiversity. The owner accepts restrictions in the interests of conservation on what the owner can do on the land, restrictions enforceable by another party, for example a non-governmental organization (NGO) with an interest in conservation or an individual

${ }^{26}$ Jégouzo, 'L'évolution des instruments du droit de l'environnement'; F.-G. Trebulle, 'Les titres environnementaux' (2011) 36(2) Revue juridique de l'environnement 203-26.

${ }^{27}$ Société Smurfit Kappa Papier Conseil d'Etat, 17 February 2016.

${ }^{28}$ See e.g. Art. L229-15 French Code de l'environnement.

${ }^{29}$ Wemaere, Streck, and Chagas, Legal Ownership and Nature of Kyoto Units and EU Allowances in Freestone, at 49-51.

${ }^{30}$ Deutsche Bank AG v Total Global Steel Ltd [2012] EWHC 1201 (Comm); Ineos Manufacturing Scotland Ltd v Grangemouth CHP Ltd [2011] EWHC 163 (Comm).

${ }^{31}$ Wemaere, Streck, and Chagas, Legal Ownership and Nature of Kyoto Units and EU Allowances in Freestone', at 52-5.

${ }^{32}$ Law Commission, Conservation Covenants (London: TSO, 2014); C. Reid, 'Conservation Covenants' (2013) 77(3) Conveyancer and Property Lawyer 176-85; C. Reid and W. Nsoh, 'Whose Legal System Is It Anyway?' (2014) 5(2) Journal of Human Rights and the Environment 112-35. 
philanthropist. Crucially the obligation that 'runs with the land', in the sense that it is enforceable not just as a contract between the original parties but also against any future owner of the land. In many legal systems, such covenants face the difficulty that only obligations that benefit neighbouring land are permitted to 'run with the land', so severely limiting the circumstances in which they work. ${ }^{33}$ But in several jurisdictions in the United States, and in Scotland, legislatures have intervened to make such covenants possible even in the absence of benefit to neighbouring land. ${ }^{34}$ Furthermore, the Law Commission for England and Wales has recommended the adoption of a similar rule in that jurisdiction. ${ }^{35}$

\subsubsection{Private Legal Actions in Respect of Environmental Harm}

The second way in which private law can act as environmental law is by granting rights to prevent or to demand compensation for environmental damage. This is the domain not so much of contract law as of tort or delict (or in some jurisdictions property law). The paradigm example is the law of nuisance or troubles anormaux de voisinage, under which claimants have under certain conditions a right to stop activities by others that degrade their environment. But claimants might also be able to establish liability on the basis of more general principles, for example the principle found in many legal systems that claimants can recover compensation from anyone who harms them intentionally or by negligence, a principle recognized to a greater or lesser degree by, for example, Articles 1240 and 1241 (previously 1382 and 1383) of the French Civil Code, $\S 823$ of the German $B G B$, and the English and American tort of negligence. In addition, some legal systems provide for strict liability for damage caused by things under the control of the defendant, for example Article 1242 (previously 1384) of the French Civil Code and the US (though not the English) interpretation of the 'Rule in Rylands $v$ Fletcher' as establishing strict liability for 'inherently dangerous (or ultrazardous) activity'. ${ }^{36}$ German law also provides for a form of strict liability but by specific statutory provision rather than in the general law, including the Environmental Liability Act of 1990, which I here classify as 'Environmental Law in Private Law' rather than 'Private Law as Environmental Law'.

The degree to which these legal rules facilitate environmental protection through private law litigation depends on a number of factors, which themselves vary across legal systems. ${ }^{37}$ They include: (1) who can sue; (2) who can be sued; (3) what forms of damage are actionable; (4) what are the conditions of liability; (5) how causation can be established; and (6) what remedies are available?

${ }^{33} \mathrm{~J}$. Gordley and A. von Mehren, An Introduction to the Comparative Study of Private Law (Cambridge: Cambridge University Press, 2006), 198.

${ }^{34}$ Reid, Conservation Covenants'; G. Korngold, 'Globalizing Conservation Easements: Private law Approaches for International Environmental Protection' (2011) 28(4) Wisconsin International Law Journal 585-638.

${ }^{35}$ Law Commission, Conservation Covenants.

${ }^{36}$ Restatement (Second) of Torts, § 520.

${ }^{37}$ See e.g. G. Kaminskaitè-Salters, Constructing a Private Climate Change Lawsuit Under English Law: A Comparative Perspective (Alphen aan den Rijn: Kluwer, 2010); M. Faure and M. Peeters (eds.), Climate Change Liability (Cheltenham: Edward Elgar, 2011). 


\subsubsection{Who Can Sue}

On who can sue, systems impose very few restrictions in their general fault-based delicts apart from the requirement that claimants have to have suffered actionable damage, but in nuisance and its equivalents one can find a very wide range of rules. At one end, in Sweden no restriction exists, since the Swedish system in principle gives everyone a right to sue for violations of the Environmental Code. ${ }^{38}$ At the other end, in Dutch law, only owners of land appear to be protected, a position also reflected in the wording of the German BGB § 906, although that provision is usually interpreted as additionally covering those with possessory interests. ${ }^{39}$ The German position is similar to that in England, where possessory interests are required in private nuisance, although that also includes interests such as easements that would not count universally as possessory. ${ }^{40}$ Beneficiaries of easements are protected in other systems, for example in Catalonia. ${ }^{41}$ English law does not, however, protect contractual licensees, ${ }^{42}$ whereas Czech and French law does extend to contractual licensees. ${ }^{43}$ French law even protects building contractors. ${ }^{44}$

\subsubsection{Who Can Be Sued}

On who can be sued, the position is similar. In the general fault-based torts, one normally finds no limitation, but in the nuisance/troubles anormaux de voisinage torts wide variation appears. In Sweden, in effect any violator of the Environmental Code is a potential defendant. ${ }^{45}$ In England the law is unclear, but the better view is that, as in Sweden, no limitation exists: anyone who causes a nuisance is liable for it regardless of their own status as a landowner. ${ }^{46}$ In France the same rule seems to apply, ${ }^{47}$ being implied in the principle announced by the courts as governing the cases: 'nul ne doit causer à autrui un trouble anormal de voisinage' ${ }^{48}$ In many systems, however, including the Dutch and the Italian, liability arises from the idea that a property owner is abusing his or her rights, and so liability is confined to owners of the land from which the nuisance emanates. ${ }^{49}$ Systemsalso

${ }^{38}$ G. Brüggemeier, A. Colombi Ciacchi, and G. Comandé, Fundamental Rights and Private Law in the European Union: Comparative Analyses of Selected Case Patterns (Cambridge: Cambridge University Press, 2010), 331.

${ }^{39}$ S. M. Santisteban and P. Sparkes, Protection of Immovables in European Legal Systems (Cambridge: Cambridge University Press, 2015), 448, 454.

${ }^{40} \mathrm{M}$. Jones, A. Dugdale, and M. Simpson, Clerk and Lindsell on Torts (London: Sweet and Maxwell, 21st edn. 2014), sections 20:63-20:69.

${ }^{41}$ Martin Santisteban and Sparkes, Protection of Immovables in European Legal Systems, at 461.

${ }^{42}$ Hunter v Canary Wharf Ltd [1997] UKHL 14; [1997] AC 655; [1997] 2 All ER 426.

${ }^{43}$ Martin Santisteban and Sparkes Protection of Immovables in European Legal Systems, at 440, 446.

${ }^{44}$ Ibid., at 446.

${ }^{45}$ Swedish Environment Code, Chapter 32, ss. 6 and 7.

${ }^{46}$ Jones, Dugdale, and Simpson, Clerk and Lindsell, at section 20:70.

${ }^{47} \mathrm{G}$. Godfrin, 'Trouble de voisinage et responsabilité environnementale' (2009) 54 Annales des Mines-Responsabilité et environnement 16-22.

${ }^{48} X$ Cass. Civ. 2e. 19 November 1986 (84-16379).

${ }^{49}$ Martin Santisteban and Sparkes, Protection of Immovables in European Legal Systems. French law originally based its equivalent of nuisance on the idea of abuse of property rights but has now 
vary in the extent to which they recognize secondary liability. For example, in systems in which any person who causes the damage is liable, another question that arises is whether a person who contracts for the damage-causing activity to be done is also liable. Similarly systems vary about whether landlords are liable for the trouble caused by their tenants. ${ }^{50} \mathrm{~A}$ related but more general issue on which jurisdictions vary is the question of when, in cases in which multiple defendants might be liable, each defendant can be held liable with respect to the whole loss, regardless of considerations of relative contributions to the loss, the issue of joint and several liability. ${ }^{51}$

\subsection{Suing the State}

Particular problems arise in using private law to sue the state. Although absolute prohibitions on using private law against the state, still the situation in French law, are not as common as they were, many jurisdictions still make suing the state more difficult than suing private parties. Although much confusion surrounds the issue, state defendants in England, for example, have frequently succeeded in persuading courts that no private law obligations exist at all where the state is accused of failing to exercise a discretion to take more action to prevent harm. ${ }^{52}$ This is especially the case if the damage flowed from a 'policy' decision of the state, one that involves the political weighing up of the benefits of different allocations of public resources. Similar rules exist elsewhere, for example in US federal law in which the Federal Tort Claims Act exempts from its scope the 'exercise or performance or the failure to exercise or perform a discretionary function or duty'. ${ }^{53}$ In addition, US law, both state and federal, operates under a broad 'political question' doctrine that immunizes on constitutional grounds controversial policy decisions, for example those affecting climate change, from private law challenge. ${ }^{54}$

\subsubsection{Actionable Damage}

moved beyond that theory. The place of abuse of right in English law is notoriously controversial. It is not a good idea to suggest to an English court that it forms part of English law: VTB Capital plc $v$ Nutritek International Corpn [2013] UKSC 5; [2013] 2 A.C. 337 at [144]; but many have tried to incorporate it: see e.g. Hubbard v Pitt [1976] 1 QB 142 at 175 per Lord Denning MR and J. W. Neyers, 'Explaining the Inexplicable? Four Manifestations of Abuse of Rights in English Law' in Nolan and Robertson (eds.), Rights and Private Law, at 309-30.

${ }^{50}$ Martin Santisteban and Sparkes, Protection of Immovables in European Legal Systems; V. WesterOuisse, 'Responsabilité pour troubles anormaux: le modèle d'une responsabilité fondée sur le dommage' (2007) 32(119) Revue de la recherche juridique, droit prospectif 1219-34; Jones, Dugdale, and Simpson, Clerk and Lindsell, at sections 20.71-20-84; Lawrence $v$ Fen Tigers Ltd (No 2) [2014] UKSC 46; [2015] AC 106.

${ }^{51} \mathrm{H}$. Koziol, Basic Questions of Tort Law from a Comparative Perspective (Vienna: Jan Sramek Verlag, 2015), 774-5.

${ }^{52}$ See Jones, Dugdale, and Simpson, Clerk and Lindsell, at sections 14-03 to 14-15.

${ }^{53} 28$ USCA s. 2680 (a).

${ }^{54}$ E. Kosoplova, 'Liability for Climate Change-related Damage in Domestic Courts: Claims for Compensation in the USA' in Faure and Peeters, (eds.), Climate Change Liability, at 189-20. 
Those sceptical of the utility of private law as environmental law often point to the third factor, actionable forms of damage, to bolster their case. ${ }^{55}$ Their argument is that private law liability systems provide no protection for the environment broadly conceived to cover such matters as biodiversity and greenhouse gas emissions. ${ }^{56}$ To some extent, broader environmental interests can be protected by proxy through the protection of narrower interests, but the problem is that climate change and reduction of biodiversity are often characterized as threats to the health or property of people not yet born and only psychologically damaging to those alive now. Indeed, one motive for creating property and contractual rights in environmental assets, in the shape of tradeable emissions permits for example, is precisely that many private law systems take a narrow view of the types of damage recognized by tort law. No such limits exist for the interests protected by contract law as long as the interests are lawful.

It is indeed the case that even in the most generous regime in terms of standing to sue, namely Sweden, individual victims may only seek compensation for 'bodily injury, material damage and pecuniary loss'. ${ }^{57}$ German and English law both limit recovery even in their general fault-based torts to specific forms of loss, although German law, in recognizing the right to a continuing business is more generous than English law in its treatment of pure economic loss and is clearer in its protection of personal freedom. ${ }^{58}$ The degree of recognition of psychological harm also varies, from some US states in which any kind of mental distress is potentially actionable to the somewhat incoherent hostility to 'secondary' psychiatric damage in England. ${ }^{59}$

In the more specific nuisance tort, English law is even more restrictive, excluding all liability for personal injury and interruption of pleasant vistas. ${ }^{60}$ Liability for interference in other matters, for example light, can only be established if the claimant has established a specific property right to those amenities. ${ }^{61}$ English law also denies protection for the flow of air in the form of breezes and the wind, ${ }^{62}$ so that in English law the operator of a wind farm would have no action against a neighbour whose activities interfered with the flow of air to the wind turbines. Other systems, however, provide for the protection a long list of amenities and may even include an eiusdem generis clause to deal with amenities the

\footnotetext{
55 e.g. Holder and Lee, Environmental Protection, Law and Policy, at 329-33; Bell, McGillivray, and Pedersen, Environmental Law, at 381 and 385.

${ }^{56}$ D. Howarth, 'Muddying the Waters: Tort Law and the Environment' (2002) 41(3) Washburn Law Journal 469-513.

57 Swedish Environment Code Chapter 32, s. 1.

${ }^{58}$ D. Howarth, 'The General Conditions of Unlawfulness' in A. Hartkamp, M. Hesselink, E. Hondius, C. Mak, and C. du Perron (eds.), Towards a European Civil Code (Alphen aan den Rijn: Wolters Kluwer/Ars Aequi Libri, 4th edn. 2011), 845-85; D. Howarth, 'The Duty of Care' in K. Oliphant (ed.), The Law of Tort (London: LexisNexis, 2014), sections 12:123-12:210.

59 Jones, Dugdale, and Simpson, Clerk and Lindsell, at sections 8:69-8:79; Howarth, 'The Duty of Care', at sections 12:130-12:172.

${ }^{60}$ Hunter v Canary Wharf Ltd [1997] UKHL 14; [1997] AC 655; [1997] 2 All ER 426.

61 Jones, Dugdale, and Simpson, Clerk and Lindsell, at section 20:147.

${ }^{62}$ Webb v Bird (1863) 13 CRNS 841, 143 ER 332.
} 
legislator has forgotten to mention, as in the Swedish Environment Code, ${ }^{63}$ although it is not clear whether the eiusdem generis clause would protect the flow of wind to wind farms.

\subsubsection{Conditions of Liability}

The heart of a private law action is the liability rule itself: in what circumstances is the defendant's conduct to be treated as actionable? The most common rule in the general torts and often used in more specific torts is an objective fault rule, namely that a reasonable person in the position of the defendant would have acted differently. The US courts have broken down the standard into three factors in a way that has influenced many other systems:

The degree of care demanded of a person by an occasion is the resultant of three factors: the likelihood that his conduct will injure others, taken with the seriousness of the injury if it happens, and balanced against the interest which he must sacrifice to avoid the risk. ${ }^{64}$

English and German law are roughly on that same page, ${ }^{65}$ although German lawyers seem to find objective standards of fault difficult to understand and to think of 'fault' as something at least residually subjective. ${ }^{66}$ In addition, English law adds a rider that some risks are so low in comparison with the benefits of taking them that the courts believe that they should not bother to ask how onerous it would have been to take further preventive measures. ${ }^{67}$

\subsection{Other Possible Variants on Fault}

In principle, the elements of the standard approach to fault could be varied, ${ }^{68}$ and as a consequence environmental actions might be made easier for claimants. A systematic approach to that variation would note that one could (1) replace the foreseeability requirement for any of the elements with a test that in effect asks whether it would be reasonable for the defendant to act in the same way now, in the light of what we have learned since the accident, a rule that was indeed proposed at one time in the United States in some product liability cases; ${ }^{69}$ (2) burdens of proof on any or all of the elements of the test could be reversed so that they lie on the defendant rather than the claimant, as in liability in French law for hospital-acquired infections; ${ }^{70}$ and (3) more relevant in actions against private parties than actions against the state, the onerousness of further

\footnotetext{
${ }^{63}$ Swedish Environment Code Chapter 32, s. 3.

${ }^{64}$ Conway v O'Brien 111 F.2d 611 (1940), at 612 per Learned Hand J.

${ }^{65} \mathrm{H}$. Kerkmeester and L. Visscher, 'Learned Hand in Europe: a Study in the Comparative Law and Economics of Negligence' (Berkeley C.A.: German Working Papers in Law, 2006).

${ }^{66} \mathrm{H}$. Koziol, Basic Questions of Tort Law from a Germanic Perspective (Vienna: Jan Sramek Verlag, 2012), 200; Koziol, Basic Questions of Tort Law from a Comparative Perspective, at 783.

${ }^{67}$ Bolton v Stone [1951] AC 850.

${ }^{68}$ See G. Calabresi and A. Klevorick, 'Four Tests for Liability in Torts' (1985) 14 Journal of Legal Studies 585-627.

${ }^{69}$ Barker v Lull Eng'g Co 20 Cal. 3d 413 (1978); Beshada v. Johns-Manville Prods. Corp. 90 N.J. 191 (1982).

${ }^{70}$ Société la clinique Bouchard Cass. Civ. 1re, 21 May 1996.
} 
precautions could be limited to the costs of further precautions for actors other than the defendant, eliminating any purely private cost for the defendant, which is at least a plausible account of how a 'risk-benefit' test might work in the definition of 'defect' in the EU Product Liability Directive. ${ }^{71}$

\subsection{Strict Liability}

Going even further are the strict liability rules to be found in, for example, Article 1242 (ex 1384) of the French Civil Code and the US 'ultrahazardous activity' doctrine, which hold those who control 'things' (or in the case of the US rule, inherently dangerous things) liable without proof of fault for the damage those 'things' cause. Japan also seems to follow the rule that dangerousness implies strict liability. ${ }^{72}$ The French rule, whose scope is notoriously wide, has been used in an environmental context to impose strict liability, for example, on a brewery for contaminating a town's water supply with waste released in the course of demolishing a building. ${ }^{73}$ The scope of the US rule is much narrower, being often interpreted as applying only to activities that cannot be carried on safely regardless of the defendant's degree of care and as not applying to any activity that is 'normal' in the purely factual sense of widespread. Nevertheless the rule has been used successfully in cases of radioactive emissions. ${ }^{74}$ The US courts trace their rule back to the English case Rylands $v$ Fletcher, ${ }^{75}$ in which the owner of a reservoir serving a factory was held liable without proof of fault for the property damage caused when water from the reservoir invaded the underground shafts of the claimant's mine. The court, reflecting, perhaps unconsciously, the replacement of a rural society by an industrial one, reasoned from an analogy with cattle trespass - that just as the owners of cattle are strictly liable for the damage their animals cause if they wander onto other people's land, so factory owners should be strictly liable if their materials wander and cause damage. ${ }^{76}$ In England, however, the rule in Rylands $v$ Fletcher never became a general rule of strict liability for dangerous activities and is increasingly treated as merely a sub-species of private nuisance dealing with one-off events as opposed to continuing activities. ${ }^{77}$ The Australian courts, further illustrating the diversity of the common law world, have rejected Rylands $v$ Fletcher in its entirety. ${ }^{78}$ In Germany,

\footnotetext{
${ }^{71}$ This view is a possible compromise between the contradictory views of English judges interpreting Council Directive 85/374/EEC of 25 July 1985, Art. 6 in Wilkes v Depuy International Limited [2016] EWHC 3096 (QB) and A v National Blood Authority [2001] 3 All ER 289.

${ }^{72} \mathrm{~K}$. Yamamoto, 'Basic Questions of Tort Law from a Japanese Perspective' in Koziol, Basic Questions of Tort Law from a Comparative Perspective, at 515-681, 636.

${ }^{73}$ C. Van Dam, European Tort Law (Oxford: Oxford University Press, 2013), 449.

${ }^{74}$ C. Bell, D. Case, and W. Brownell, Environmental Law Handbook (Plymouth: Government Institutes, 2011).

${ }^{75}$ (1865-66) L.R. 1 Ex. 265, (1868) L.R. 3 H.L. 330

${ }^{76}$ Fletcher $v$ Rylands (1865-66) L.R. 1 Ex. 265, 280-5 per Blackburn L.

${ }^{77}$ Jones, Dugdale, and Simpson, Clerk and Lindsell, at sections 20:44-20:46.

${ }^{78}$ Ibid., at section 20:46.
} 
strict liability for dangerousness is not a principle of general tort law but it does appear in specific statutes, including the Environmental Liability Act of $1990 .^{79}$

\subsection{Special Rules in Nuisance/Troubles Anormaux}

In the nuisance or troubles anormaux torts, the liability rule tends to be stricter than in the general fault torts. The approach taken by most systems is to ask whether the degree of interference is beyond that which a reasonable person in the position of the claimant should be expected to tolerate, ${ }^{80}$ an approach that comes to the question of liability from the point of view of the claimant rather than from that of the defendant. Applying this tolerance approach usually includes considering the intensity, timing and duration of interference and, crucially the type of neighbourhood involved ${ }^{81}$-in the words of a nineteenth-century English court, referring to areas of London that are still very different, "What would be a nuisance in Belgrave Square would not necessarily be so in Bermondsey'. ${ }^{82}$ Some systems, particularly the Swedish and the German systems, assess levels of reasonable toleration by applying regulatory standards. Others, for example the English system, use regulatory standards merely as guides. Most systems employ a 'hypersensitive claimant' rule, under which an interference does not become unreasonable just because of unusual vulnerabilities of the claimant. ${ }^{83}$ Interestingly, systems seem to adopt the reasonable tolerance approach whether they come to the problem as a matter of the law of obligations or as a matter of the law of property.

Some systems use a more defendant-centred fault-like standard at least for some purposes-for example English law uses a slightly modified fault standard when the damage was caused by a third party or by natural causes on the defendant's land, ${ }^{84}$ and Spanish law, outside Catalonia, has no specific nuisance action and so applies the standards of the general torts. ${ }^{85}$ Some systems make a distinction between physical encroachment on and damage to land, in which liability is close to absolute with very few excuses or defences available, and annoyances that do not involve physical encroachment or damage, in which the tolerance rule applies. ${ }^{86}$ In England, for example, nuisance including an element of physical encroachment cannot be justified by the nature of the neighbourhood. ${ }^{87}$ It is worth mentioning, however, that nuisance by encroachment is difficult to distinguish from trespass to land, at least without referring back to historical distinctions between types of

\footnotetext{
${ }^{79}$ Koziol, Basic Questions of Tort Law from a Germanic Perspective, at 230-2; T. Lundmark, 'Systemizing Environmental Law on a German Model' (1998) 7 (Winter) Dick. Journal of Environmental Law \& Policy 1-47.

${ }^{80}$ Martin Santisteban and Sparkes, Protection of Immovables in European Legal Systems, at 465; Yamamoto, 'Basic Questions of Tort Law from a Japanese Perspective', at 607.

${ }^{81}$ Martin Santisteban and Sparkes, Protection of Immovables in European Legal Systems, at 465.

${ }^{82}$ Sturges v Bridgman (1879) 11 Ch. D. 852, 865 per Thesiger $L$.

${ }^{83}$ Martin Santisteban and Sparkes, Protection of Immovables in European Legal Systems, at 465.

${ }^{84}$ Sedleigh-Denfield v O'Callaghan [1940] AC 880; Goldman v Hargrave [1967] 1 AC 645; Ward v Coope [2015] EWCA Civ 30; Jones, Dugdale, and Simpson, Clerk and Lindsell, at section 20-2.

${ }^{85}$ Martin Santisteban and Sparkes, Protection of Immovables in European Legal Systems, at 461.

${ }^{86}$ Ibid., at 456.

${ }^{87}$ Jones, Dugdale, and Simpson, Clerk and Lindsell, at section 20:08.
} 
action that have no modern resonance or use. As ever, English law suffers from its lack of a straightforward vindicatio, ${ }^{88}$ and has produced an excess of substitutes for it.

The defendant's conduct is not strictly relevant in a tolerance standard, since the determinative issue is the degree of interference from the claimant's point of view. But it might become relevant at least indirectly in systems that recognise a 'reciprocity' or 'normal behaviour' rule. English law is such a system. ${ }^{89} \mathrm{~A}$ reciprocity rule says that no one can sue for interference at a level they would want themselves to be allowed to make. A normal behaviour rule is that no one can sue for activities considered normal by reasonable people, the underlying thought being that a reasonable person in the position of the claimant would not object to a neighbour pursuing reasonable objectives in a reasonable way. These rules, especially in their objective form, allow courts to compare the interests of the parties. They also provide a functional equivalent to the concept of abuse of right in those systems that lack such a concept. If the defendant targets the claimant maliciously, for no good reason, a reasonable person in the position of the claimant would give no weight to the defendant's purposes.

One challenge the tolerance standard faces in the environmental law context is that it might fail to lead to liability in cases of cumulative effects over large populations and over long periods of time. It is possible to envisage situations in which the degree of interference for each individual claimant might be small enough to be tolerable but the long term cumulative effect on, for example, biodiversity or climate might be very great.

\subsection{Private Law Liability Rules and the Polluter-Pays Principle}

Some commentators believe that all the liability rules in use in private law, with the possible exception of strict liability under Article 1242 of the French Civil Code and its equivalents, are inadequate as environmental law because they fail to respect the polluter-pays principle. ${ }^{90}$ The basic point they make is that both fault-based liability and tolerance-based liability allow polluters to escape having to pay. That seems difficult to deny in the case of fault-based liability in its classic ex ante form, since under that rule polluters do not pay for pollution where the cost of avoiding it would have seemed too high at the time, regardless of how matters turned out. In the case of tolerance-based liability, however, one might counter that the defendant's argument is not that the pollution was justified at the time but that, according to the standards of the society concerned, what has taken place should not count as 'pollution' and so the defendant is not a 'polluter'. That arguably remains so even if we admit arguments based on reciprocity or normal behaviour, since the position is still that interferences are allowed if they have social support.

\subsubsection{Causation}

${ }^{88}$ P. Sparkes, 'Declarations of Title: 1883 and All That' (2016) 80(2) Conveyancer and Property Lawyer 118-37.

${ }^{89}$ R. Burnett-Hall and B. Jones, Environmental Law (London: Sweet and Maxwell, 2012), sections 6:013-6:019.

${ }^{90}$ e.g. G. Cross, 'Does Only the Careless Polluter Pay? A Fresh Examination of the Nature of Private Nuisance' (1995) 111 Law Quarterly Review 445-74. 
Claimants in private law tort actions invariably need to prove that a causal link can be made between the damage they have suffered and the defendant. Causation is two issues rather than one, although some systems run the two together. The first issue (often called 'factual causation') is whether one can identify a factual link between the damage and the defendant's actions, for which the usual starting point is whether the harm would have happened but for the defendant's tort. ${ }^{91}$ The second (often called 'legal causation'), which is possibly better analysed under recognized damage or conditions of liability, is whether the defendant should take responsibility for a specific consequence. Both issues are relevant in both the general fault-based torts and the nuisance/troubles anormaux torts.

\subsection{Factual Causation}

The factual link issue is one of those parts of the law that works better in practice than in theory. In theory it is full of problems and puzzles, most of which arise out of the difficulty of understanding causation of a particular event in a particular case without specifying a counterfactual, that is without mentally varying some aspect of the sequence of events as they actually happened and asking what would have happened in those different circumstances. ${ }^{92}$ In fault-based torts it is tolerably straightforward to specify the counterfactual. The claimant normally has to show that if the defendant had acted properly, that is if the defendant had reached the required standard of behaviour, the claimant would not have suffered the damage.${ }^{93}$ Although several ways of meeting the standard might exist, the defendant is not required to have gone beyond minimal compliance and so the lawful alternative' used in analysis is usually the one least onerous for the defendant. In the case of strict liability, however, although often treated as self-evident, the concept of factual causation is theoretically rather unclear, since it is not obvious which counterfactual one should choose. Is it what would happened if the defendant had done nothing, or if the defendant had done something else, and if the latter, which something else? Doing nothing is not necessarily the least burdensome option for the defendant since the defendant will often have engaged in the activity as part of a profit-making business. Factual causation under the tolerance rule is also not entirely clear. If one asks what would have happened had the defendant acted properly one immediately undermines the claimant-centred nature of the test. But if one starts with the point of view of the claimant it is not clear which counterfactual one should choose. In practice, however, both in strict liability versions of the general tort and in nuisance/troubles de voisinage the counterfactual chosen, or perhaps merely presupposed, is that the defendant did not engage in any activity at all.

But even ignoring the issue of which counterfactual to choose, factual causation creates other obstacles for claimants. Typically environmental problems involve multiple potential polluters and multiple potential victims. It is often difficult for individual claimants to show that the damage they suffered was caused by the actions or activities of specific defendants. A further complication comes if a certain degree of pollution is considered acceptable,

\footnotetext{
${ }^{91}$ Koziol, Basic Questions of Tort Law from a Comparative Perspective, at 773.

${ }^{92}$ D. Lewis, 'Causation' (1973) 77(17) Journal of Philosophy 556-67; D. Lewis, 'Causation as Influence' (2000) 97(4) Journal of Philosophy 182-97.

${ }^{93} \mathrm{~K}$. Grechenig and A. Stremitzer, 'Der Einwand rechtmäßigen AlternativverhaltensRechtsvergleich, ökonomische Analyse und Implikationen für die Proportionalhaftung' (2009) 73(2) Rabels Zeitschrift fuer ausländisches und internationales Privatrecht 336-71.
} 
which might allow some or even all polluters to claim that taken by itself their particular contribution would have been insufficient for the threshold to have been crossed. Another argument arises in cases in which the threshold would have been crossed by the individual contributions of more than one polluter by themselves, allowing each of them to claim that actionable damage would have occurred anyway even if they had not made their own contribution.

Systems vary in their response to these difficulties. Some offer claimants very little help, at least in the general torts, although some of those systems, such as the German, offer help instead through 'environmental law in private law', for example by creating a presumption of causation where individuals sue for compensation arising out of breaches of specific protective statutes such as the Environmental Liability Act. ${ }^{94}$ Other systems offer a great deal of help in the general law. French law, for example, in addition to creating a legal presumption of causality where the defendant has committed a criminal offence, has a concept of collective fault for situations in which the same damage is caused by more than one defendant, allowing the claimant to sue any of the group without having to identify all of the possible defendants. ${ }^{95}$ Moreover, the Cour de cassation decided that in a situation where one of two defendants must have caused the damage but it was not clear which one, each was liable unless it could prove it was not the cause, ${ }^{96}$ a solution similar to that developed in North America. ${ }^{97}$ Even the English courts have held that where, because of the existence of multiple possible causes, it is inherently impossible for the claimant to establish causation with regard to one defendant, the claimant is allowed to show merely that the defendant was at fault and that fault of that type materially increases the risk of the harm occurring. ${ }^{98}$ In the United States courts in some states have created a form of liability in which defendants who each have contributed to a risk by manufacturing a dangerous product that harmed a large number of claimants but where the market share of each was less than 50 per cent, so that one could not say that it was more probable than not that any of the defendants caused the harm, the defendants should all be held liable in proportion to their market share. ${ }^{99}$ Specifically for the nuisance tort, the English courts have long applied a rule that if more than one person contributes to creating a nuisance, all are liable, even if the degree of interference created by each of them would not have amounted to a nuisance. ${ }^{100}$ In addition the French courts have taken the lead in solving causation problems by recognizing a lost chance of avoiding recognized damage as itself a recoverable form of damage. ${ }^{101}$

\subsection{Legal Causation}

\footnotetext{
${ }^{94}$ Van Dam, European Tort Law, at 324-5.

${ }^{95}$ Ibid., at 325-8.

${ }^{96}$ Litzinger Cass. Civ. 2e, 5 June 1957; Van Dam, European Tort Law, at 331-4.

${ }^{97}$ Summers v Tice 33 Cal.2d 80 (1948); Cook v Lewis [1951] SCR 830; [1952] 1 DLR 1.

${ }^{98}$ Fairchild v Glenhaven Funeral Services Ltd [2002] UKHL 22.

${ }^{99}$ Sindell v. Abbott Laboratories (1980) 26 Cal.3d 588 (1980).

${ }^{100}$ Pride of Derby \& Derbyshire Angling Association Ltd v British Celanese Ltd [1952] 1 All ER 1326.

${ }^{101}$ Van Dam, European Tort Law, at 337-9.
} 
Turning to the second aspect of causation, the attribution of responsibility, the standard issue is whether, in particular in the light of other causes of the harm, to limit the legal responsibility of a defendant whose actions or activities admittedly caused harm in a factual sense. A common limitation is to restrict responsibility to 'foreseeable' consequences of the defendant's actions or activities, ${ }^{102}$ but systems tend to ignore the foreseeability criterion where the harm was unforeseeable only in extent rather than in kind and where the reason for the lack of foreseeability was an unusual weakness or vulnerability in the claimant (the 'eggshell skull' rule or the rule that defendants must take claimants as they find them). ${ }^{103}$ Many systems also ignore the foreseeability limitation where the defendant is guilty of intentional harm, adopting the rule that intended consequences are never too remote. Some systems find defendants liable where they have created a risk that someone else might harm the claimant even where the defendant is not responsible for the acts of the third party on some other ground, for example where the defendant is the third party's employer. On the other hand, other systems exonerate defendants where the third party's intervention deliberately and wrongfully took advantage of the situation created by the defendant even where the intervention was foreseeable. ${ }^{104}$

The foreseeability restriction is particularly controversial in nuisance or troubles anormaux torts. Given the tolerance rule, it is not at all clear why the foreseeability of damage from the point of view of the defendant should be relevant. The test is whether the degree of interference as it turned out to affect the claimant is one a reasonable person in the position of the claimant would tolerate, not whether a reasonable person in the position of the defendant would have started the activity in the first place. Nevertheless some systems insist on foreseeability. ${ }^{105}$ As a purely practical matter, however, since in most nuisance or troubles anormaux cases the matter has only reached the courts because the defendant has refused to stop the activity even after the claimant has complained about it, any foreseeability requirement will automatically have been fulfilled.

\subsubsection{Remedies}

In most systems successful claimants can obtain a court order, enforceable by penal measures, that the offending activity should cease or at least be reduced to the tolerance level, together with monetary compensation for recognized damage caused before the activity stops. ${ }^{106}$ In some systems an injunction or court order is the primary remedy and claims for damages need to be filed separately under separate tort theories that may or may not succeed even if the action for an injunction has succeeded. ${ }^{107}$ In contrast, in England the action for damages is primary and the injunction remedy discretionary. Until 2014, however, the injunction was treated as almost automatic. Since then English law has joined Germany

\footnotetext{
102 Ibid., at 342-3.

${ }^{103}$ See P. Pierre and F. Leduc, La Réparation Intégrale en Europe: Études comparatives des droits nationaux (Brussels: Larcier, 2012).

${ }^{104}$ Topp v London Country Bus (South West) Ltd [1993] 1 WLR 976; [1993] 3 All ER 448; Howarth, 'The Duty of Care', at section 12:45.

105 Jones, Dugdale, and Simpson, Clerk and Lindsell, at section 20:28.

${ }^{106}$ Martin Santisteban and Sparkes, Protection of Immovables in European Legal Systems, at 465-6. 107 Ibid., at 466 .
} 
and many US states in saying that injunctions can be refused if the public interest requires. ${ }^{108} \mathrm{~A}$ similar though lesser effect arises if the court suspends the injunction until the defendant no longer needs to continue the nuisance-causing activity. ${ }^{109}$

These possibilities of refusing or suspending injunctions in turn raise a further question of how the level of compensation should be affected by the refusal or suspension of the injunction, since damages in respect of the future are a very different matter from damages in respect of the past. In effect, the defendant is being allowed to expropriate the claimant's interest and so should be required to buy out that interest at a reasonable price set by the court. In Sweden, the law takes this thought to its logical conclusion and provides that victims of nuisances that render properties 'unprofitable to the owner, wholly or in part, or great detriment arises in connection with its use' are entitled to require the defendant to buy out their interest at a value set by the statute on expropriation. ${ }^{110}$ Another possibility, much discussed in the economic literature, is that instead of the court refusing an injunction and ordering 'permanent' damages, the court grants the injunction but requires the claimant to make an off-setting payment to the defendant, to recompense the defendant for having to cease an otherwise beneficial activity. ${ }^{111}$

\subsubsection{Particular Problems of Climate Change Litigation}

Although the utility of tort/delictual liability for environmental protection purposes varies with the choices a system makes on each of the elements of liability, a consensus was growing that, despite some initial optimism, ${ }^{112}$ delictual liability was not well-suited to litigating long-term problems such as climate change. US-based litigation, for example, eventually failed through a combination of problems around the immunity of state bodies and causation, in particular claimants having to show that they have suffered damage that would not have happened had the specific defendant acted differently in a specific way. ${ }^{113} \mathrm{~A}$ degree of optimism was, however, restored by the Urgenda litigation in the Netherlands. ${ }^{114}$

${ }^{108}$ Lawrence v Fen Tigers Ltd (No. 1) [2014] UKSC 13; [2014] AC 822; D. Howarth, 'Noise and Nuisance' (2014) 73(2) Cambridge Law Journal 247-50; Lundmark, 'Systemizing Environmental Law on a German Model'; Boomer v Atlantic Cement Company, Inc 26 N.Y.2d 219 (1970).

${ }^{109}$ Pontin, Nuisance Law and Environmental Protection.

${ }^{110}$ Swedish Environment Code Chapter 32, s. 11.

${ }^{111}$ Spur Industries, Inc v. Del E. Webb Development Co 108 Ariz. 178 (1972); Guido Calabresi and A. D. Melamed, 'Property Rules, Liability Rules, and Inalienability: One View of the Cathedral' (1972) 85(6) Harvard Law Review 1089-128.

${ }^{112}$ D. Grossman, 'Warming Up to a Not-So-Radical Idea: Tort-based Climate Change Litigation' (2003) 28 Columbia Journal of Environmental Law 1-61, but see, for less optimism around the same time, Howarth, 'Muddying the Waters'.

${ }^{113}$ See e.g. Kosoplova, 'Liability for Climate Change-related Damage in Domestic Courts'. For a more positive assessment of this litigation, at least in its broader effects, see J. Peel and H. Osofsky, Climate Change Litigation (Cambridge: Cambridge University Press, 2015).

${ }^{114}$ Urgenda Foundation v The Netherlands C/09/456689/HA ZA 13-1396 The Hague District Court Chamber for Commercial Affairs 24 June 2015; affirmed on appeal C/09/456689/ HA ZA 13-1396 The Hague Court of Appeal 9 October 2018; R. Cox, 'The Decision of the Hague District Court in 
The Urgenda Foundation, an environmental NGO, brought successful proceedings in the Dutch civil courts alleging that the Netherlands government's climate change policy amounted to a tort under Article 6:162 of the Dutch Civil Code. Article 6:162 declares tortious 'an act or omission in violation of a duty imposed by law or of what according to unwritten law has to be regarded as proper social conduct', a standard interpreted by the Dutch courts in way that has yielded conditions of liability very close to the standard US three-part analysis. ${ }^{115}$ Usefully for claimants, however, the Dutch courts treat the problems of state discretion as a factor in assessing fault rather than as a separate issue. The claimants overcame the usual problem of showing that they were suffering recognizable damage that a change in behaviour by the defendant would alleviate by arguing that that climate change frustrated their primary purpose as an association, which was 'to stimulate and accelerate the transition processes to a more sustainable society'. That meant that the future effects of climate change constituted current damage to Urgenda. On appeal the court also recognised Urgenda's interest as a matter of human rights. On causation the claimants succeeded at first instance in persuading the court to combine two approaches favourable to claimants: that all those who contribute to creating unlawful damage should count as having made the damage unlawful; and that a loss of a chance should count as recognised damage. On appeal they succeeded on the basis that in Dutch law an applicant for an injunction, as opposed to claimant for damages, has to show the existence only of a real risk of the relevant harm.

\subsubsection{Refusal to Enforce Environmentally Damaging Agreements}

The third way in which private law can act as environmental law is by refusing to enforce otherwise enforceable voluntary arrangements, such as contracts or trusts, on the ground that executing the agreement would have damaging environmental effects. This aspect of private law as environmental law is as yet more a theoretical possibility than common practice. Moreover its practical effects might not be clear-cut: sociologists since Weber have long pointed out that lack of legal enforceability might not deter the making of agreements between people who have other reasons to trust one another to perform their obligations. ${ }^{116}$ It is worthwhile, however, to set out how such a legal result might come about.

As the new Article 1162 of the French Code Civil says: 'Le contrat ne peut déroger à l'ordre public ni par ses stipulations, ni par son but, que ce dernier ait été connu ou non par toutes les parties'. Two provisions of the German BGB between them produce a similar effect: § 134 says, 'Ein Rechtsgeschäft, das gegen ein gesetzliches Verbot verstößt, ist nichtig, wenn sich nicht aus dem Gesetz ein anderes ergibt' and § 138(1) says, 'Ein Rechtsgeschäft, das gegen die guten Sitten verstößt, ist nichtig'. English law, although in this area notoriously difficult to apply or even to understand, in principle says something similar:

the Climate Case Urgenda Foundation v The State of the Netherlands' (2016) Journal of Planning \& Environment Law 323-41.

${ }^{115}$ Kelerluik Hoge Raad, 5 November 1965.

${ }^{116}$ M. Weber, Economy and Society, trans. G. Roth and C. Wittich, vol. 1 (Berkeley C.A.: University of California Press, 1978), 336-7. 
contracts that are illegal or against public policy are vulnerable to being found either void or unenforceable. ${ }^{117}$ Similar rules apply to trusts. ${ }^{118}$

These provisions raise the question of whether the law can refuse to enforce contracts whose terms or objectives involve environmental degradation. Contracts to violate specific environmental standards or statutory rules - for example contracts illegally to dump toxic waste-would almost certainly fall foul of the rules against illegality or public policy in most, if not all, jurisdictions. Contracts of insurance under which insurers provide cover to operators against having to pay fines for violations of environmental law are also likely to be declared void. ${ }^{119} \mathrm{~A}$ wider issue is whether the same result might arise for contracts whose terms or objectives facilitate damage to biodiversity or to the climate. Compliance with a specific regulatory scheme, the EU ETS for example, would presumably protect contracts from illegality or public policy rules, but what about contracts in non-traded sectors? The coming into force of the Paris Agreement means that it is difficult to deny that international public policy favours urgent action to reduce greenhouse gas emissions. Some states have domestic legislation enshrining greenhouse gas emission targets in law. ${ }^{120}$ The Urgenda case shows that it is at least possible for courts to hold unlawful a specific policy trajectory incompatible with avoiding serious damage to the climate. On the other hand parties threatened with the voiding of their contracts will presumably argue that, as long as the global or relevant national target for non-traded greenhouse gas emissions for the period of the contract is greater than the emissions envisioned by the contract, the contract should not be treated as contrary to public policy or illegal. It would still be possible, they would argue, to fulfil the obligations both of the general law and of the contract. But that leads to an interesting problem of cumulative causation: what if the volume of emissions envisaged by all the contracts in a jurisdiction taken together exceed the relevant limit? Are all the contracts nevertheless valid? What about contracts made in circumstances in which the parties knew or should have known that given the volume of emissions already contracted for the emissions envisaged by their contract would lead to the limit being exceeded? Moreover, what is the effect of the rule in the new French code 'que ce dernier ait été connu ou non par toutes les parties'? In a regime that followed that rule, it is possible that all the relevant contracts would be void.

One problem with the public policy and illegality doctrines of contract law is that their invocation is a matter for the parties to the contract rather than for the public authorities. As a result parties might be reluctant to raise public policy or illegality points if they are

${ }^{117}$ H. Beale, Chitty on Contracts (London: Sweet and Maxwell, 32nd edn. 2016), sections 16:00116:002.

${ }^{118}$ J. McGhee, Snell's Equity (London: Sweet and Maxwell, 33rd edn. 2014), sections 22:064-22:066.

${ }^{119} \mathrm{~J}$. Birds, B. Lynch, and S. Milnes, MacGillivray on Insurance Law (London: Sweet and Maxwell, 13th edn. 2015), section 14:046.

${ }^{120}$ e.g. the UK's Climate Change Act 2008, Switzerland's CO2 Act 2013, and France's Energy Transition Law 2015. A wide variety of other statutes related to climate change have been passed which take measures short of instituting formal targets. See the Grantham Institute's collection at: http://www.Ise.ac.uk/GranthamInstitute/research-theme/governance-and-legislation/ and M. Nachmany, S. Fankhauser, J. Setzer, and A. Averchenkova, Global Trends in Climate Change Legislation and Litigation: 2017 Update (London: Grantham Research Institute on Climate Change and the Environment, 2017). 
parties to other contracts in which a finding of unenforceability or voidness would be very inconvenient. On the other hand, in systems in which the state can make private law contracts, for example in the English system, one can envisage a situation in which, following a change of government, a state body might look for ways to escape long term contracts in the energy sector formed on the basis of the previous government's policy. This scenario is particularly enticing in jurisdictions that treat binding the government's ability to make policy changes in areas of vital national interest as itself a potential ground for radically re-construing or voiding its contracts. ${ }^{121}$

One question that would arise out of the voiding of energy contracts following a change of government is whether the operators would be entitled to compensation. Systems that treat contracts under public law differently from private law contracts often compensate contractors where the contract is affected by changes in policy, ${ }^{122}$ but the position in jurisdictions in which the state makes only private law contracts might be different. A question of classification might also be relevant: is the reason the state can change the contract a matter of contractual interpretation, illegality, or lack of contracting capacity? That classification will determine whether the affected party will be able to claim reparation on the basis of unjustified enrichment. In particular, if the reason is illegality, the contractor might be left uncompensated. ${ }^{123}$

\subsubsection{Summary}

The breadth of possibilities across the three examples of private law as environmental law and within each example is great and not easy to summarize. We might, however, construct two extreme types as a way of clarifying the position. One extreme would be a jurisdiction in which the use of private law as environmental law is minimized. The other extreme would be where it is maximized. In the first option, no legislative provision would exist to make environmental assets such as carbon credits tradeable, conservation contracts would not run with the land, no one would have standing to sue in negligence or nuisance for longterm environmental damage, remedies would be restricted to money compensation for past damage, the conditions of liability would be restricted to fault (perhaps even to intentional wrongdoing), causation rules would exclude cumulative causation, the responsibility for pollution would be easily diverted to other actors on grounds of lack of foreseeability, governments would have immunity from private law actions, and public policy rules in contract would require knowing breach of specific legal rules. In the latter, all environmental assets would be recognized as tradeable and enforceable against the whole world, standing to sue for long-term environmental damage would be granted to all citizens, the primary remedy would be injunctions, the liability rule would be strict, cumulative causation would be recognized, the transfer of responsibility to others would be restricted to situations of deliberate and wrongful intervention (or even eliminated completely), governments would have no immunity even for political decisions, and contracts would be void if they tended to

\footnotetext{
${ }^{121}$ Beale, Chitty on Contracts, at sections 11:007-11:009.

${ }^{122}$ Compagnie Nouvelle du Gaz de Deville-Lès-Rouen Conseil d’Etat 10 January 1902; Société Chimique Conseil d'Etat 8 November 1957.

${ }^{123}$ Beale, Chitty on Contracts, at section 16:194.
} 
make more difficult the fulfilment of important policy objectives, including long-term environmental objectives. Table 1 illustrates these extreme options.

Table 1

\begin{tabular}{|c|c|c|}
\hline & Minimum & Maximum \\
\hline Environmental assets & Not tradeable & $\begin{array}{l}\text { Tradeable and enforceable erga } \\
\text { omnes }\end{array}$ \\
\hline Recognized damage & $\begin{array}{l}\text { No one has standing to sue } \\
\text { for long-term environmental } \\
\text { damage }\end{array}$ & $\begin{array}{l}\text { Everyone has standing to sue } \\
\text { for long-term environmental } \\
\text { damage }\end{array}$ \\
\hline Primary remedy & Damages & Injunction \\
\hline Liability rule & Fault & Strict \\
\hline Factual causation & No cumulative causation & Cumulative causation \\
\hline Legal causation & $\begin{array}{l}\text { Lack of foreseeability } \\
\text { exonerates }\end{array}$ & $\begin{array}{l}\text { Deliberate intervention } \\
\text { exonerates }\end{array}$ \\
\hline Government immunity & Complete & $\begin{array}{l}\text { None, even for 'discretionary' } \\
\text { or 'policy' decisions }\end{array}$ \\
\hline $\begin{array}{l}\text { Public policy rule in } \\
\text { contract }\end{array}$ & $\begin{array}{l}\text { Specific knowledge of breach } \\
\text { necessary }\end{array}$ & $\begin{array}{l}\text { Knowledge of breach } \\
\text { unnecessary }\end{array}$ \\
\hline
\end{tabular}

No system takes either of these views in its totality and for each variable a number of other possible rules exist that lie between the two. But the table gives a rough checklist for judging how far a system has gone in adapting its private law for use as environmental law.

\subsection{Environmental Law in Private Law}

We now turn to environmental law in private law. The question is how environmental regulation that takes forms different from private law, essentially criminal law and regulation, interacts with private law. This is potentially a very large topic. Only two dimensions of the relationship are taken up here, each of which has a plausible claim to be significant. The first is the extent to which private law claimants can invoke environmental crimes as a basis for legal actions even if the relevant statute fails to mention the possibility of a private law action. The second is the degree to which defendants in private law actions can defend themselves by showing that they had complied with environmental regulatory standards.

The two dimensions are linked in the sense that liability on the basis of violation of a criminal or regulatory statute is only possible if the crime has actually been committed or the regulation broken. But beyond that no purely logical connection exists. It is a matter of public and legal policy which combination of rules on these issues a jurisdiction adopts. A jurisdiction might, for example, combine saying that environmental crimes automatically give rise to torts with saying that regulatory compliance is a defence in tort. In such a jurisdiction, determinations made by the state about permitted levels of pollution are 
dominant in private law. But a jurisdiction might instead say that crimes do not automatically create torts and that regulatory compliance is not a defence to private law actions. In that system private law determines for itself the levels of pollution it will tolerate, independent of the views of the state regulatory authorities. Moreover, those are not the only possibilities. A jurisdiction could refuse to allow private law actions on crimes but at the same time allow regulatory compliance to be a defence in private law. A jurisdiction could even allow private law actions on crimes but refuse to make regulatory compliance a defence to its general torts.

It might be objected that the combination of no torts on crimes plus allowing a regulatory compliance defence makes no sense. Criminal polluters will be prosecuted anyway so why not reinforce the deterrent by adding in the prospect of damages? The counter is that in systems that give prosecutors a broad discretion to refuse to prosecute (some do not give such a discretion, notably Germany) the point of the combination is not to prevent pollution but quite the opposite: it is consistently to protect potential polluters from legal interventions from anyone except the state.

The final combination, torts on crimes but no regulatory compliance defence, might draw the opposite criticism that if private claimants can bring to a halt activities the regulatory system allows, the regulatory system would be undermined. In addition, if the defendant commits no crime because it has a permit and thus no tort arises on the crime, why should the permit not also undermine any other action against the defendant? But the combination does make sense if the courts in that jurisdiction have a power to refuse or suspend injunctions in exchange for enhancing compensation. The policy intention behind the combination would be to put extra pressure on polluters through allowing tort actions on environmental crimes but also to ensure that polluters who benefit from regulatory permissions have to compensate those whom their activities harm even when they commit no crime. ${ }^{124}$

A rough and ready way of understanding the possibilities, ignoring the subtleties of the law we are about to sketch, is given in Table 2.

Table 2

\begin{tabular}{|l|l|l|l|}
\hline \multicolumn{2}{|l|}{} & \multicolumn{2}{|l|}{ Regulatory compliance a defence in private law? } \\
\cline { 3 - 4 } \multicolumn{2}{|l|}{} & Yes & No \\
\hline $\begin{array}{l}\text { Environmental } \\
\text { crime } \\
\text { automatically } \\
\text { a tort? }\end{array}$ & Yes & $\begin{array}{l}\text { State determinations } \\
\text { dominant in private law }\end{array}$ & $\begin{array}{l}\text { Pollutees compensated for } \\
\text { consequences of state action }\end{array}$ \\
\cline { 2 - 4 } & No & $\begin{array}{l}\text { State protects polluters from } \\
\text { private law actions }\end{array}$ & $\begin{array}{l}\text { Private law determinations } \\
\text { dominant in its own sphere }\end{array}$ \\
\hline
\end{tabular}

\subsubsection{Environmental Crimes as the Basis of Private Law Actions}

${ }^{124}$ Howarth, 'Noise and Nuisance'. 
The general relationship between criminal law and tort/delict varies to a very great degree across legal systems, ${ }^{125}$ and even within the same system. ${ }^{126}$ The variation is not a simple matter of common law systems versus civilian systems or codified versus non-codified systems. One of the biggest differences is between English law and the law of most US states, even though all these jurisdictions purportedly trace their law back to the same (and much misunderstood) nineteenth-century English case. ${ }^{127}$ In English law the very existence of a criminal penalty in a statute creates an initial presumption that the statute was not intended to create a tort. ${ }^{128}$ In the United States, the opposite is the case. ${ }^{129}$

Liability regimes differ across a number of variables. ${ }^{130}$ They include: Is it a condition of liability that the criminal statute can be interpreted as protecting the interests of the claimant or people like the claimant? Are the types of loss the same or different from those in the general fault torts or the nuisance/troubles torts? Do the elements of liability in the crime determine in whole or in part the liability rule in the tort, and in particular do strict liability crimes produce strict liability torts? Are causation rules the same or different from other torts? Does the violation of a criminal standard result in the same levels of compensation as in private law, or less?

The requirement that the criminal statute must be interpreted as protective of the claimant's interests before it can be used to create a tort is a common but not universal rule. ${ }^{131}$ It is a characteristic of Germanic legal systems. ${ }^{132}$ It is less apparent in Frenchderived systems, largely as a result of their use of the procedural device of the partie civile, under which tort claimants are represented and make their claims in the criminal trial. ${ }^{133} \mathrm{In}$

${ }^{125}$ Dyson (ed.), Comparing Tort and Crime.

${ }^{126}$ M. Geistfeld, 'Tort Law in the Age of Statutes' (2014) 99 lowa Law Review 957-1020.

${ }^{127}$ Gorris v Scott (1874) L. R. 9 Ex. 125, which concerned the loss at sea of some sheep which would not have been lost had the defendant complied with regulations designed to prevent the importation of diseased sheep. The misunderstanding is that nearly all commentators on both sides of the Atlantic fail to notice that Gorris is not a tort case at all, but rather a contract case. The issue was not, as is usually claimed, whether the purpose of the relevant legislation was to protect the owners of sheep from losing them at sea but whether the purpose of the legislation was to alter the balance of contractual risk of such a loss between the owner of the sheep and the owner of the ship. See Pollock B., ibid., at 130-1. What is more plausible: that Parliament had no intention in the relevant legislation to alter the parties' contract or that Parliament intended to distinguish between different ways in which sheep might die?

${ }^{128}$ Jones, Dugdale, and Simpson, Clerk and Lindsell, at section 9:13.

${ }^{129}$ B. Lindahl, Modern Tort Law: Liability \& Litigation (St Paul: Thomson Reuters, 2016), § 3:73.

${ }^{130}$ M. Dyson, 'Tortious Apples and Criminal Oranges' in Dyson (ed.), Comparing Tort and Crime, at 416-75.

${ }^{131}$ M. Dyson, 'Tort and Crime' in M. Bussani and A. Sebok (eds.), Comparative Tort Law: Global Perspectives (Cheltenham: Edward Elgar, 2015), 93-121, 114; Dyson (ed.), Comparing Tort and Crime, at 436-7.

${ }^{132}$ Koziol, Basic Questions of Tort Law from a Germanic Perspective, at 67.

${ }^{133}$ Dyson, 'Tort and Crime', at 96-7. 
England and the law of the US states, protectiveness appears as a formal requirement for liability but in the United States many examples can be found of it being disregarded. ${ }^{134}$

On types of loss, normally the same restrictions apply as in tort law generally, even in those systems, such as the German and the Swedish, which have explicit environmental liability laws that envisage tort liability on the basis of breaches of environmental regulation. ${ }^{135}$ One peculiarity, however, is the situation in English law under the crime of public nuisance. Public nuisance is a common law crime of uncertain scope that can be used to base actions in tort of even more uncertain scope. ${ }^{136}$ The crime is said to consist of doing anything, except by lawful authority, that endangers 'the life, health, property, morals, or comfort of the public, or to obstruct the public in the exercise or enjoyment of rights common to all'. Omissions are also covered if they involve the failure to discharge a legal duty. Surprisingly the courts recognize a tort arising out of this crime that can be used by anyone who suffers 'special damage', which is to say damage more than that suffered by members of the public generally. ${ }^{137}$ Significantly, that special damage can include forms of loss not normally recoverable in general tort actions, such as pure economic loss, ${ }^{138}$ and forms of loss not recoverable in ordinary private nuisance actions, such as personal injury. ${ }^{139}$ This flexibility of public nuisance encouraged environmental activists in the United States, where its origins in criminal law seem to have been forgotten, ${ }^{140}$ to use it as the basis of actions against both public and private organisations for excessive greenhouse gas emissions. All these actions have failed, though largely because of constitutional rather than private law considerations. ${ }^{141}$

The degree to which the elements of the crime or regulatory provision control or replace the liability rule of the tort is a much discussed issue in the United States. ${ }^{142}$ In jurisdictions in which the tort claimant sits alongside the criminal prosecutor, howeverwhich includes not only systems derived from the French but also the Swedish system - no

\footnotetext{
${ }^{134}$ Geistfield, 'Tort Law in the Age of Statutes'.

${ }^{135}$ Swedish Environmental Code Chapter 32, s. 1.

${ }^{136}$ J. Spencer, 'Public Nuisance-A Critical Examination' (1989) 48(1) Cambridge Law Journal 55-84. For a brave attempt at rescuing public nuisance from accusations of incoherence, albeit at the cost of drastically narrowing its scope, see J. W. Neyers, 'Reconceptualising the Tort of Public Nuisance' (2017) 76(1) Cambridge Law Journal 87-115.

${ }^{137}$ Jones, Dugdale, and Simpson, Clerk and Lindsell, at section 20:03.

${ }^{138}$ Spencer, 'Public Nuisance', at 82-3.

${ }^{139}$ Burnett-Hall and Jones, Environmental Law, at section 6:091. This flexibility has not prevented criticism of public nuisance on the ground that where no private party has suffered 'special damage' or, more to the point, every victim has suffered the same damage, no private right of action arises and victims must rely on the public authorities to bring an action: K. Stanton and C. Willmore, 'Tort and Environmental Protection' in J. Lowry and R. Edmunds (eds.), Environmental Protection and the Common Law (Oxford: Hart Publishing, 2000), 93-113.

${ }^{140}$ T. Merrill, 'Is Public Nuisance a Tort?' (2011) 4(2) Journal of Tort Law 1-54.

${ }^{141}$ Merrill (2012) 1-2; Kosoplova, 'Liability for Climate Change-related Damage in Domestic Courts'.

${ }^{142}$ Geistfield, 'Tort Law in the Age of Statutes'.
} 
gap is discernible between the conditions of criminal and delictual liability. The same is true, at least in principle, in English law. ${ }^{143}$

An important issue is whether the mechanism in effect creates strict or even absolute liability torts. The answer is often yes, ${ }^{144}$ although a prior question is whether a system allows strict or absolute crimes in the first place. Some, in particular the German system, find the idea of crimes with no mental element difficult to accept. ${ }^{145}$ Nevertheless some writers refer to liability under the German Environmental Liability Act of 1990 as 'strict'. ${ }^{146}$

On causation, the most important departure from the ordinary rules is the rule of the German Environmental Liability Act that once a general tendency for the type of establishment run by the defendant to cause the relevant type of damage has been ascertained a presumption of causation arises, unless the defendant has complied with all relevant regulatory requirements. ${ }^{147}$

Finally on levels of compensation, if the action on the crime or regulation is treated as a tort or delict, levels of compensation should not differ from those obtainable in the ordinary torts. In some systems, however, a separate system of compensation operates in the criminal courts which bears little or no relation to the tort/delict system. In such systems, for example in English law, in criminal court-ordered compensation, because of its limited scope and perhaps its requirements to take into account the defendant's ability to pay, compensation amounts can be much lower than tort damages. ${ }^{148}$

\subsubsection{Environmental Regulatory Compliance as a Defence in Private Law Actions}

One difference across systems that does appear to map onto the difference between common law and civil law is whether regulatory compliance constitutes a defence to private law actions. In the United States and in England, regulatory compliance, including compliance with zoning or planning regulation, is not usually a defence to a nuisance action, in contrast to, for example, the German system, in which regulatory compliance is an important defence. ${ }^{149}$ Regulatory compliance also appears to be a defence in, for example, Bulgaria, France, and Italy. ${ }^{150}$

On closer inspection, however, the difference becomes somewhat indistinct. The provision of the French Code de la construction et de l'habitation that seems to provide

\footnotetext{
${ }^{143}$ Jones, Dugdale, and Simpson, Clerk and Lindsell, at section 9:59.

${ }^{144}$ Dyson (ed.), Comparing Tort and Crime, at 95 (France).

${ }^{145}$ Ibid., at 155-7.

${ }^{146}$ Lundmark, 'Systemizing Environmental Law on a German Model'

${ }^{147}$ Ibid.

${ }^{148}$ See Dyson, 'Tort and Crime', at 101-2.

${ }^{149}$ Martin Santisteban and Sparkes, Protection of Immovables in European Legal Systems, at 448; Lundmark, 'Systemizing Environmental Law on a German Model'; Barr v Biffa Waste Services Ltd [2012] EWCA Civ 312; [2013] Q.B. 455; Lawrence v Fen Tigers Ltd (No. 1) [2014] UKSC 13; [2014] AC 822; Jones, Dugdale, and Simpson, Clerk and Lindsell, at section 20:90.

${ }^{150}$ Martin Santisteban and Sparkes, Protection of Immovables in European Legal Systems.
} 
protection against private law actions, Article L. 112.16, is far from comprehensive. It covers only activities that can be described as 'agricole, industrielle, artisanale ou commerciale' and so does not apply to co-proprietors of the same block of flats or, apparently, to golf courses. ${ }^{151}$ Retrospective permissions also do not count. ${ }^{152}$ On the other side of the divide, English law does allow statutory authority to provide a defence and not just where statutes expressly say so, for example the statute governing planning permission for national infrastructure projects. ${ }^{153}$ Statutory authority can also work where the necessary implication of the statute was to provide a defence, at least as long as the defendant acted without negligence in how the statutory authority was implemented. ${ }^{154}$

\section{Conclusion}

The main goal of this chapter has been to demonstrate the great variety of ways in which private law and environmental law interact. I hope that it has at least achieved that much. But beyond that, I hope it has helped to lay to rest some myths about that interaction. For example it is far from true that the form the interaction takes is determined by whether a legal system can be classified as 'common law' or 'civil law'. In a few cases, for example regulatory compliance as a defence in private law, that classification does seem to mark a boundary, but in many other respects it does not. More difference exists within these classifications than between them, for example between French and German law and between English law and the law of the US states. Moreover, some of the most interesting systems, for example the Swedish system, stand aside from the simple civil law/common law divide.

Another myth the chapter helps to lay to rest is that the relationship between private law and environmental law is necessarily antagonistic. No doubt an antagonistic relationship is possible and has occurred from time to time in various places, but so are other types of more cooperative relationship. A complete melding of the two is perhaps not likely, since private law can be used for a variety of goals to which environmental law is largely indifferent-the vindication of property rights, for example, or the achievement of corrective justice-but that variety of goals in private law is just as likely to result in friction inside private law as in friction with environmental law.

The final myth is that policy-makers are faced with fixed private law systems and that their only options for dealing with the relationship between private law and environmental law lie in the latter. As Table 1 illustrates, policy-makers possess a large number of options in private law too. No doubt legislators need to be careful in making new combinations that they have taken into account all of benefits of the status quo and that they have also taken into account possible consequential effects on other parts of the private law system, but those concerns do not make private law reform impossible.

\footnotetext{
${ }^{151}$ Godfrin, 'Trouble de voisinage et responsabilité environnementale'.

${ }^{152}$ Société Calcialiment Cass. Civ. 2e 14 June 2007.

${ }^{153}$ Planning Act 2008, s. 158.

${ }^{154}$ Jones, Dugdale, and Simpson, Clerk and Lindsell, at sections 20:87-20:90.
} 
The last point to make, however, is addressed more to environmental lawyers than to private lawyers. As Table 2 illustrates, one cannot assume that state policy takes into account only environmental goals. More specifically one cannot classify state policy crudely as either pro- or anti-environment. Combinations of rules that appear contradictory when analysed from that simple point of view might have a broader logic if one takes other goals into account. Environmental lawyers are entitled as citizens to campaign for whatever environmental goals they espouse but as legal analysts they should not forget those other goals. 